\title{
Who has the Custody over the Fertilized Egg in Vitro?
}

\section{Ghannam Mohamed* \\ Professor of Criminal Law, Qatar University, Qatar}

*Corresponding author: Ghannam Mohamed, Professor of criminal law, Qatar University, College of Law, Qatar, Email: gmohamed@qu.edu.qa

\section{Mini Review}

Volume 4 Issue 4

Received Date: December 20, 2021

Published Date: December 30, 2021

DOI: $10.23880 /$ abca-16000214

\section{Abstract}

The issue of fertilized egg in vitro has been the object of controversy in the American courts. Some courts have recognized its right to future life while others have ruled that it was no more than pre-embryo and hence lacking the potential for actual life and the right to future life. The debate became more intense when this fertilized oven was stored in a private laboratory during the marital life followed by the divorce and a dispute between spouses over the future of this oven. In this regard, the American courts concluded to the common custody of the former spouses over this stored egg. At the same time, it endorsed the right to refuse the procreation specially in the case of the former husband invoking his right not to have children.

Keywords: Fertilized Egg; Embryo; Right to Procreation; Custody; In Vitro; Fetus

\section{Introduction}

The developing of biological sciences has large repercussion on the right to procreation specially concerning the fertilization of the egg in vitro. The question has become more complicated when an egg from the wife with the sperm of the husband during their marriage and was stored in a special laboratory with their mutual consent, but the spouses separated by the divorce and one of them is no more willing to go ahead with the procreation. This is the object of this issue in this article.

\section{Arguments in Favor of the Wife's Custody}

The problem of keeping the fertilized egg in a medical bank designated for this was raised with regard to the holder of the right to guardianship of that egg, i.e. the decisionmaker in determining its fate.

That problem was raised in the Tennessee Supreme Court ruling in Davis v. Davis, where it came to fertilizing a wife's egg from her husband's sperm before her divorce, which had been kept in a laboratory. After her divorce, the wife asked the lab keeping the fertilized egg to deliver that egg because she wanted to go ahead with the pregnancy, but the former husband objected. So she asked the court to deliver her that fertilized egg [1].

\section{Arguments in Favor of the Husband's Custody}

Because the husband objected, she filed a lawsuit before the trial court, requesting the delivery of the fertilized egg. The court ruled in favor of the wife based on the expert's report which stated that the egg after fertilization becomes a human soul that has the right to a future life, which is the wife's request, while the husband was unwilling to have children.

The husband appealed the first ruling before the Court of Appeal. The report of four experts came in favor of the husband defense, on the basis that the matter was related to a pre-embryo before the formation of the embryos, while the report of one of the experts came in favor of the wife on the grounds that the matter was related to the beginning of the fetus. 
Experts have distinguished between the fetus and the embryo, which is the stage prior to the formation of the embryo, and the pre-embryo, which is the stage before the formation of the embryo. The latter starts from two weeks and ends with three weeks until the leech stage begins after three and up to eight weeks, after which the fetus begins to form, i.e. starting from the ninth week.

In the opinion of the Court of Appeal, as long as the tissue formed did not reach the level of the fetus, his right to the future life was not established and the husband and wife had a common interest in deciding its fate. Thus, the court excluded the character of the person and inclined to conclude to the character of the thing. However, it did not specify that the disposal of this embryo is carried out by a decision that belongs to both the husband and the wife, despite the fact that it ended with the existence of joint guardianship between the husband and wife over that embryo.

It is noted that determining who has custody of the embryo is of legal importance when conducting scientific experiments on it; is it permissible without the consent of the wife? Tennessee law says this is not permitted. However, it does not resolve the problem at hand in this dispute.

The expert's status was challenged before the trial court on the ground that he specializes in genetics and not in reproductive and gynecological sciences.

The American Committee on the Ethics of Fertility Medicine had an opinion on this subject. This view is represented in looking at the embryo, not as a person, as it did not reach the level of a human being and not as a mere tissue. In light of the foregoing, it is necessary for the legislator to intervene with legislation specifying the decision-maker on this embryo, whether in the case of scientific experiments or in the case of its transfer or disposal. It is also necessary to determine the extent to which the agreement between the spouses regarding the fate of the embryo is respected, the extent to which the contract is respected between them and the medical center that keeps that embryo, and the fate of that embryo in the event of a divorce between the spouses. The fate of the embryo should also be determined in the event of a dispute between the spouses: whether it will be kept for a period of time or will it be disposed of when they are unable to agree on the fate of that embryo.

In any case, it is not permissible for the legislator to give priority to the interest of the embryo and its right to the future life by weighing it despite the objection of one of the two parties. The reason for this is due to the conflict that may arise with the refusing husband's right not to have children, which is a constitutional right.
Determining the right to respect a person's decision not to have children is due to the fact that this decision belongs to the right to private life, even if it was not established by an express independent text. Some older constitutions, such as the US Constitution, did not enshrine explicitly the right to a private life. However, the American judiciary considers this right a constitutional right because it attaches it to the exercise of rights and freedoms in general. The right to a private life is supplemented by those rights and freedoms for which there is an express provision [2].

\section{The Joint Custody over the Egg in Vitro}

Applying this rule, the Supreme Court of the United States ruled unconstitutional to impose "sterility" on perverted and mentally handicapped prisoners to prevent them from having children, and defects in their genes that threaten their potential children $[3,4]$. The court based its ruling in the case of Skinner v. Oklahoma on the fact that the right to procreation belongs to the constitutional rights, despite the absence of an explicit provision for this in the American Constitution. The court concluded that this right is rather an outgrowth of the rights and freedoms enshrined in the Constitution [5-11].

Judicial rulings were not limited to consecrating the right to procreation as a constitutional right, but also addressed the right not to have children as a constitutional right, and this is represented in the prevention of childbearing and sometimes in the practice of abortion with conditions where life is not completed in the fetus $[12,13]$.

Accordingly, the Tennessee State Court of Appeals ruled that the two jointly have the right to dispose of the fertilized egg [14]. The woman who married someone else and specified in her application the desire to donate the egg to any woman who does not give birth. The husband objected to that request. Submit the matter to the state Supreme Court. Therefore, the Court of Appeal overturned the ruling of the trial court and ruled that the fertilized egg (the embryo) is not a human being, and that the man has the right to refuse to have children as long as the pregnancy has not begun, and it was referred to the trial court in order for the spouses to agree on a decision that the matter is not unique to either of them. The Tennessee Supreme Court has previously ruled that a fetus is not a human being [15-18]. Thus, this applies a fortiori to the embryo and the leech.

The Tennessee Supreme Court held that it was not a human being but a fetus and thus did not recognize that it had a right to life independent of his parents' will. Also, the absence of this right means that the mother does not have the right to hold this fetus to life. In this she disagrees with 
the trial court, which approved this right for the wife.

The Supreme Court held that there is a conflict of interest between the former wife's interest in having children and the husband's (in not having children). The court favored the husband's interest in not having children, because having children places a heavy psychological burden on him, as he will be deprived of raising his son in the event of his completion, while the wife's interest can be achieved through another fertilization of the new husband. This interest is further weakened due to the wife's desire to donate the attached egg to another mother who does not give birth, and therefore the balance will be weighed in favor of the husband, according to the court's opinion.

In that case, the court did not consider the fact that the development of the ovum and the appearance of a child at a date later than the divorce has no effect in light of the development of the culture in this regard, in addition to the fact that many legislations allow the existence of a single mother and a single father as well. This consideration has not been addressed by Arab laws, and it needs legislative intervention, as the religious opinion (fatwa) is in favor of the permissibility of fertilization of the egg as long as this occurs from the husband [15-18]. The issue remains to be addressed in the event that the fertilized egg is left by a couple separated later by divorce occurred and they did not agree on its fate. Here, legislative intervention is also required.

The Tennessee Supreme Court overturned the ruling on the grounds that the expert in its favor of the right of fetus to life was not a medical ethics professional and instead was specialist in genetics rather than pregnancy and childbirth specialist [19].

The Medical Ethics and Medical Safety Act of 2005 was passed in the state to regulate new biology research following the start of research on fertilized egg stem cells and the emergence of cloning technology and its application in the field of stem cells. The question as to whether cloning was intended for procreation or whether its purpose was treatment has emerged too. In the first case, legislation tends to ban cloning, while it tends to allow scientific research aimed at treatment [20].

\section{Conclusion}

This short study on the custody over the fertilized egg in vitro elucidated the opinion of the American courts concerning this subject. They are in favor of a joint custody of spouses over this fertilized egg. This decision applied to the case when the spouses separated by divorce and we think that it applies too when the marriage. Anyhow the courts ruled that the pre-embryo has an intermediate status between the thing and the human being. Because it is not a thing, it could not be the object of property. And because it is not a human being, it has no right to a future life.

Finally, it is recommended that the legislator intervene be regulation the condition in which the fertilized egg may be stored and the solution to be implemented if a dispute emerged in the couple after divorce as to the future of this egg.

\section{References}

1. Davis v Davis, Junior Lewis Davis, Plaintiff-Appellee, v Mary Sue Davis, Defendant-Appellant (1992) Supreme Court of Tennessee, at Knoxville. US Law, Case Law, Codes, Statutes \& Regulations.

2. (1928) Olmstead v. United States, 277 U.S. 438, 478, 48 S. Ct. 564, 572, 72 L. Ed. 944.

3. Eisenstadt v. Baird (1972) 405 U.S. 438, 453, 92 S. Ct. 1029, 1038, 31 L. Ed. 2d 349.

4. Carey v.Population Services International (1977) 431 U.S. 678, 685, 97 S. Ct. 2010, 2016, 52 L. Ed. $2 d 675$.

5. Griswold v. Connecticut (1965) 381 U.S. 479, 85 S. Ct. 1678, 14 L. Ed. 2d 510.

6. Roe v. Wade (1973) 410 U.S. 113, 93 S. Ct. 705, 35 L. Ed. 2d 147.

7. Wisconsin v. Yoder (1972) 406 U.S. 205, 92 S. Ct. 1526, 32 L. Ed. 2d 15.

8. Prince v. Massachusetts (1944) 321 U.S. 158, 64 S. Ct. 438, 88 L. Ed. 645.

9. Cleveland Board of Education v. LaFleur (1974) 414 U.S. 632, 94 S. Ct. 791, 39 L. Ed. 2d 52.

10. Pierce v. Society of the Sisters of the Holy Names of Jesus and Mary (1925) 268 U.S. 510, 45 S. Ct. 571, 69 L. Ed. 1070.

11. Bellotti v. Baird (1979) 443 U.S. 622, 99 S. Ct. 3035, 61 L. Ed. 2d 797.

12. Prince v. Massachusetts (1944) 321 U.S. 158, 64S. Ct. 438, 88L. Ed. 645. (Parental control over the education or health care of their children subject to some limits).

13. Roe v. Wade (1973) 410 U.S. 113, 93S. Ct. 705, 35L. Ed. $2 \mathrm{~d} 147$. (States interests in potential life overcomes right to avoid procreation by abortion in later stages of pregnancy). 


\section{Annals of Bioethics \& Clinical Applications}

14. Davis v. Davis (1992) 842 S.W.2d 588.

15. Hamby v. McDaniel (1977) Tenn.559 S.W.2d 774.

16. Durrett v. Owens (1963) 212 Tenn.614,371 S.W.2d 433.

17. Shousha v. Matthews (1962) *595 Drivurself Service, 210 Tenn. 384, 358 S.W.2d 471.
18. Hogan v. McDaniel (1958) 204 Tenn.235,319 S.W.2d 221.

19. Islamic Ruling on the use of Artificial Insemination.

20. Jhalani M (2008) Protecting Egg Donors and Human Embryos-The Failure of the South Korean Bioethics and Biosafety Act. WILJ 17(3). 